\title{
The stall in fertility decline in rural, northeast, South Africa: the contribution of a self-settled, Mozambican, refugee sub-population.
}

\author{
Latifat Ibisomi $^{1}$ a, b, Jill Williams ${ }^{\text {b, }}$, Mark A. Collinson ${ }^{b, d}$ and Stephen Tollman ${ }^{b, d, e}$ \\ aDemography and Population Studies, Faculty of Humanities, \\ University of the Witwatersrand, South Africa \\ ${ }^{b}$ MRC/Wits Rural Public Health and Health Transitions Research Unit, School of Public Health, \\ Faculty of Health Sciences, University of the Witwatersrand, South Africa \\ 'Institute of Behavioral Science, University of Colorado Boulder, USA \\ dUmeå Centre for Global Health Research, Umeå University, Sweden \\ eINDEPTH Network, Ghana
}

\begin{abstract}
Using longitudinal data from the Agincourt Health and socio-Demographic Surveillance System (HDSS) in rural South Africa, this paper examines the role of the fertility of self-settled, former Mozambican refugee sub-population on the stall in fertility decline in the Agincourt HDSS from 1993 to 2009. The Agincourt HDSS fertility trend is decomposed to quantify the relative contribution of the Mozambicans to fertility changes. Results show that fertility level declined by about 1.5 children per woman over the period and the level remain around 2.5 children per woman in the last eight years of the period examined suggesting a stall in fertility decline in the sub-district population covered by the HDSS. However, while the fertility of the Mozambicans fell consistently over the period, there was a reversal in the fertility decline of South African women residing in the area suggesting that the overall stalls are attributable to stalls in fertility decline among South African women.
\end{abstract}

Keywords: Fertility Stall; South Africa; Mozambican Refugee

\section{Résumé}

En utilisant des données longitudinales de l' Santé Agincourt et système de surveillance socio- démographiques (HDSS) en Afrique du Sud rurale, cet article examine le rôle de la fertilité de l'auto- réglé , ancien souspopulation de réfugiés mozambicains sur le décrochage en baisse de la fécondité dans la Agincourt HDSS 19932009. L'évolution de la fécondité Agincourt HDSS est décomposé de quantifier la contribution relative des Mozambicains à l'évolution de la fécondité . Les résultats montrent que le niveau de la fécondité a diminué d'environ I,5 enfants par femme au cours de la période et le niveau reste autour de 2,5 enfants par femme dans les huit dernières années de la période examinée suggérant une preuve de décrochage de stands en baisse de la fécondité dans la population sous-district couvert par la HDSS. Cependant, alors que la fécondité des Mozambicains est tombé régulièrement sur la période, il y avait une inversion de la baisse de la fécondité des femmes sud-africaines résidant dans la région ce qui suggère que les étals généraux sont imputables à des stalles en baisse de la fécondité chez les femmes sud-africaines.

Mots clés: Fertilité Stall Afrique du Sud Mozambique Réfugiés

\footnotetext{
${ }^{1}$ Corresponding author: Latifat Ibisomi University of the Witwatersrand, South Africa, Emails: libisomi@yahoo.com; Latifat.Ibisomi@wits.ac.za, Telephone: +27 780872521, Fax: +27 117174336
} 


\section{Introduction}

Although Africa has experienced considerable decline in fertility for over half of a century now, the region still has the highest regional population growth rate and is expected to maintain a growth rate of $2 \%$ through the next half century (Bloom, 20II). The region is also projected to account for $49 \%$ of global population growth over the next forty years, increasing its share of the world population from $15 \%$ to $24 \%$ (Bloom, 20I I). The persistent relatively high population growth rate in Africa is in part due to delayed onset of fertility transition in the continent. In addition, there is evidence of a stall' in the fertility transition (at above four children per woman) in some of the countries such as Kenya and Ghana that had been at the forefront of fertility decline in the region (Schoumaker, 2008; Ezeh, Mberu \& Emina, 2009; Shapiro \& Gebreselassie, 2008; Garenne, 2008; Moultrie et al., 2008; Bongaarts, 2006, 2008; Westoff \& Cross, 2006).

Although none of the studies gave explicit explanation on the causes of the stall, some of the reasons proffered for the observed stall in fertility decline include: changes in the proximate determinants of fertility such as a stall in contraceptive use and an increase in desired number of children. These were noted to be as a result of the reduced commitment to family planning programmes in recent times, which has reversed the gains in promoting small family size values and use of contraception. The bias of the available services to married women to the detriment of adolescents may also have contributed to increase in adolescents childbearing. Further, the observed increase in the fertility desires of women has been attributed to the HIV/AIDS pandemic, which caused insurance and replacement effects as women who have experienced the death of a young child are more likely to want another child while others may have more than desired with the hope that some will survive after death has taken its toll ${ }^{2}$. The worsening socio-economic challenges faced by countries in the region have also being fingered as a cause of the stall (Ezeh, Mberu \& Emina, 2009; Bongaarts 2008; Westoff \& Cross 2006).

Further, the levels, patterns and trends in fertility in the region especially, in sub-Saharan Africa have been influenced by other happenings in the subregion including political instability and armed conflict. Between 1987 and 2007, 20 African countries experienced armed conflict (Bastick, 591
Grimm \& Kunz, 2007. p. 27). Most of the armed conflicts in Africa are non-state conflicts, which are fought between militias, rival guerrilla groups, clans, warlords or organised communal groups (Human Security Brief, 2006). In 2007, about 3.5 million people were refugees in Africa (O'Hare \& Southall, 2007) and according to the UNHCR (20I2), there were 2.7 million refugees in sub-Saharan in $20 \mathrm{I}$, most of whom (75-93\%) moved to neighbouring countries. Armed conflicts have implications on refugees' fertility as well as the fertility of the host communities. Refugees travel with their fertility profiles and values, which may be different from those of the host population and may have an impact on the overall fertility of the host community. Armed conflict may lead to an increase in fertility levels of refugees in response to high child mortality. It may also lead to a decline in fertility in response to refugees' economic instability, life disruptions and marital separation (Williams et al., 2013; Schindler \& Bruck, 20I I; Verwimp \& Van Bavel, 2005).

However, the possible contribution of the fertility of refugee or displaced populations on the fertility transition trajectory of host countries is unclear. The Agincourt health and demographic surveillance system (Agincourt HDSS) site in rural northeast South Africa offers a good prospect to study the relative contribution of the fertility of former refugees to the fertility level and trend of the host community. The Agincourt HDSS is to the west of southern Mozambique border and one-third of its population is made up of people of Mozambican origin, the majority of who entered the neighbouring South African area around the mid-eighties at the height of the Mozambican civil war (Kahn et al. 2007, 2012).

\section{Literature review: Fertility decline and stall in South Africa}

Historically, South Africa was at the forefront of fertility decline in Africa (Shapiro \& Tambashe, 2002; Caldwell \& Caldwell, 2002). Several studies have documented fertility decline in South Africa (Palamuleni, Sabiti \& Makiwane, 2007; Camlin, Garenne \& Moultrie, 2004; Udjo, 2003; Moultrie \& Timaeus, 2002; Caldwell \& Caldwell, 2002; Swartz, 2002; Sibanda \& Zuberi, 1999). These studies estimated that the total fertility rate in South Africa declined from a high rate of 6.7 in the 1960's, to an average of five children per woman in the 1980's 
and to around 2.9 in 1998. The National Statistics Office in South Africa (StatsSA) gave a TFR estimate of 2.86 in 200I, 2.73 in 2006 and 2.38 in 2010 (StatsSA midyear estimates, 20I I). This means that between 1960 and 2010, South Africa experienced a substantial decline of about 4.3 children per woman. The fertility decline in South Africa has been mainly attributed to the vigorous large scale national family planning programme that was launched by the

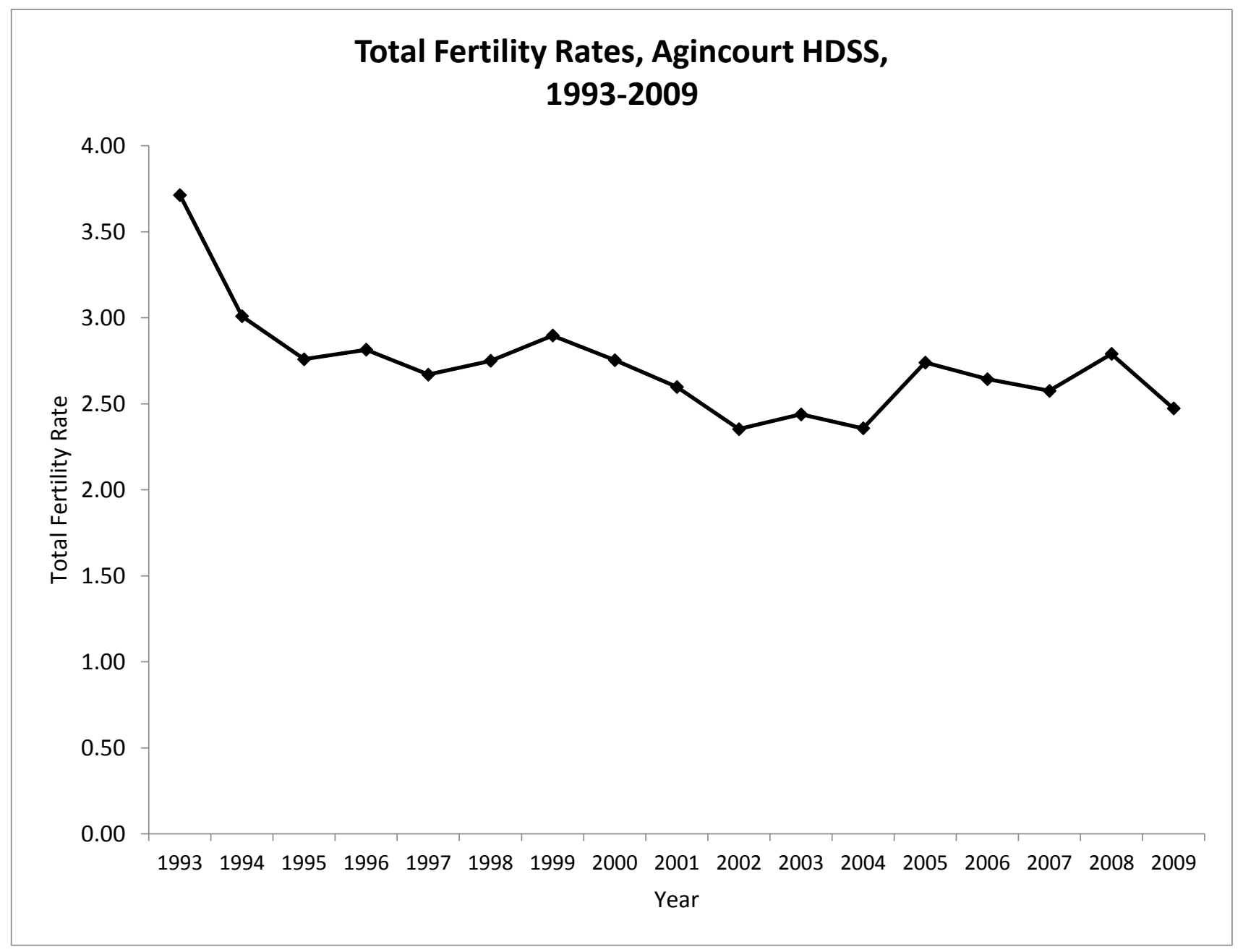

Figure I: Trend in Total Fertility Rate in the Agincourt sub-district, 1993-2009

Apartheid government in 1974, which was primarily aimed at reducing the population of the African population group (Camlin, Garenne \& Moultrie, 2004). While the fertility transition in South Africa as a country has not stalled during the transition from 6.7 in the 1960's to 2.38 in 2010, fertility research in rural South Africa indicated stall in fertility decline (Garenne, 2008; Moultrie et al., 2008) suggesting that the national level estimates obscure the variations that exist at sub-group levels in the country. In the specific case of South Africa, high non-marital and adolescent fertility; the rollout of treatment for HIV (which may have allowed HIVpositive women to consider the possibility of childbearing) and use of condoms for dual protection against pregnancy and HIV (which could lead to greater level of contraceptive failure and unintended pregnancy) may have contributed significantly to the fertility stall (Moultrie et al. 2008; Gustafsson \& Worku, 2007; Kaufman, de Wet \& Stadler, 200I; Garenne, Tollman \& Kahn, 2000).

One rural area in South Africa where stalls in fertility decline have been noted is in the north-east sub-district of Agincourt, covered by the Agincourt health and demographic surveillance system (Agincourt HDSS) since 1992. Using retrospective birth histories, Garenne \& colleagues (2007) estimated that fertility level in the area was about 6.0 children per woman in 1970, and this began to decline around 1980, only to be halted by the influx of Mozambican refugees, who had higher fertility level despite being of shangaan ethnic origin as the 
native South Africans living in the area. Fertility decline resumed for both groups around 1990 and the total fertility rate at the beginning of data collection at the Agincourt HDSS was about 4.0 children per woman.

Using prospective data from 1992 on, Garenne and colleagues (2007) noted a brief stagnation in fertility from 1996-1999. This brief stall in fertility decline can be seen in Figure I where TFR slightly increased from about 2.8 in 1995 to 2.9 in 1999. Figure I also shows a more recent and more protracted stall in the fertility decline that happened after 2002. While the total fertility rate reached close to replacement level in 2002 (2.35 children per women), subsequent fertility shows an upward trend, going as high as 2.79 children per woman in 2008. Overall, the lack of fertility decline in seven years after 2002, meets the general definition of a stall in fertility decline at the Agincourt sub-district.

Williams and colleagues (2013) found that the fertility of self-settled refugees from Mozambique declined significantly from 1993 to 2002 . The Total Fertility Rate for self-settled former Mozambican refugees fell from 4.99 in 1993 to a low of 2.79 in 2002. They concluded that over time, former Mozambican refugees were adopting the fertility patterns of South African women and these patterns were driving their overall fertility down. Overall fertility of self-settled former Mozambican refugees, however, remained higher than overall fertility of native South Africans over the period observed (1993-2009). The fertility decline of former Mozambican refugees also stalled, from 2002 to 2008. Although Williams et al (2013) described the decline in fertility of former Mozambican refugees over time, there has been no systematic examination to date of the stall in fertility decline from 19951999 and the more recent protracted stall from 2002-2009 in the Agincourt HDSS. The relative contribution of the former Mozambican refugees' higher fertility vis-à-vis South African women's fertility during this time is also unclear. Therefore, in this paper, we examine the contribution of the fertility of former refugees of Mozambican origin in fertility decline and stall in the former homeland area in South Africa from 1993-2009. In analysis, we decompose the Agincourt fertility trend to quantify the relative contribution of the two resident subpopulations (the South African natives and the Mozambican self-settled former refugees) to fertility changes in the area over segmented periods. We 593 hypothesize that as fertility declined in the area, the relative contribution of former Mozambican refugees' higher fertility increased and has been driving the stall in fertility decline in the area.

\section{Data and methods}

Since the baseline census in 1992, a regular vital events update has been conducted at the Agincourt Health and socio-Demographic Surveillance System (HDSS), with an almost annual cycle of data collection from 1992 to 1998 and strictly annual cycle from 1999 to date. Routine data collection includes information on births, deaths, migration and other vital events. The data for this study comes from the prospective information collected on births to women resident in the Agincourt sub-district from 1993 to 2009. As part of the routine data collected on fertility and related issues, detailed information on pregnancies of women within the borders of the surveillance site and the outcome of the pregnancies are collected. The completeness and accuracy of the Agincourt HDSS data on infants have been noted to be comparable to available national data sources (Kahn et al, 2008). Further details on the study area and the method of data collection are described elsewhere (see for example, Kahn et al. 2012).

Although the HDSS coverage was expanded to 26 villages in 2007, this analysis is based on the 21 villages initially covered by the HDSS to ensure that estimates for the same population are being compared over the analysis period. South African women are all women of South African origin and Mozambicans are women of Mozambique origin. The majority of the Mozambican women comprises of former refugees and to a lesser extent, voluntary Mozambican immigrants who have been entering the area since 1994. According to Williams et al. (20/3), the percentage of in-migrants from Mozambique was minimal for the time period analysed. Until 2007, less than $4 \%$ of the Mozambican population in the HDSS were inmigrants. By 2009 , $17.6 \%$ of the Mozambican population in the HDSS were in-migrants.

The sub-district has high levels of temporary labour migration with more than half of households containing at least one adult labour migrant, defined as a household member spending the more than six months a year residing at the place of employment, but remaining connected to the rural household (Collinson, 2010). Adult women are increasingly part of this labour migration stream, which can also affect 
fertility patterns. In the appendix, trends of adult labour migration are given, from 1994 to 2011 , by sex and age group.

To quantify the contribution of the fertility of Mozambican residents to fertility change in the HDSS population, we decomposed the change in fertility from period $t_{1}$ to $t_{2}$ into three components: (I) change in the proportion of South African women, (2) change in total fertility rates of South African women, and (3) change in total fertility rates of Mozambican women as follows:

$$
\begin{aligned}
& \Delta \text { TFR }=5 \sum_{x} 1 / 2\left(F_{x s a}{ }^{(t 2)}+F_{x s a}{ }^{(t)}\right) *\left(k_{x s a}{ }^{(t 2)}-k_{x s a}{ }^{(t)}\right) \\
& +5 \sum_{x} 1 / 2\left(F_{x m z}{ }^{(t 2)}+F_{x m z}{ }^{(t)}\right)^{*}\left(k_{x m z}{ }^{(t 2)}-k_{x m z}{ }^{(t)}\right) \\
& +5 \sum_{x} 1 / 2\left(k_{x s a}{ }^{(t 2)}+k_{x s a}{ }^{(t)}\right) *\left(F_{x s a}{ }^{\left({ }^{2} 2\right)}-F_{x s a}{ }^{(t)}\right) \\
& +5 \sum_{x} 1 / 2\left(k_{x m z}{ }^{(t)}+k_{x m z}{ }^{\left({ }^{(t)}\right)}\right) *\left(F_{x m z}{ }^{(t 2)}-F_{x m z}{ }^{(t)}\right)
\end{aligned}
$$

Adapted from Lindstrom and Woubalem (2003). where $F_{\mathrm{xsa}}$ and $F_{\mathrm{xmz}}$ are age-specific fertility rates of South African and Mozambican women, respectively; $k_{x s a}$ and $k_{x m z}$ are age-specific proportion of South African and Mozambican women, respectively. This formulation was introduced by Kitagawa (1955) for decomposing Crude Birth Rates (CBR) and later extended to TFR by Retherford and Ogawa (1978). The formulation has metamorphosed over time and has been used to estimate relative contribution of changes in group-specific fertility rates to fertility decline. Most of the application of the decomposition method has been to decompose fertility into marital and non-marital births. In this study we apply it to decompose changes in fertility between two resident populations - South Africans and Mozambicans residing in the sub-district. We chose to conduct the decomposition by periods of spikes and troughs in the overall fertility rate of the area. Further, the age pattern of fertility over the stall periods and the proportion of women with third births are examined. We use standard formula to compute total fertility rate (TFR) and age specific fertility rate (ASFR).

\section{Results}

Total Fertility rates (TFR) for South Africans and Mozambicans

Figure 2 shows the fertility levels in the two subpopulations. Fertility levels were quite different in the two sub-populations during the 1990s, but became increasingly similar in pattern since 2000 . Fertility levels since then have been fluctuating and converging in the two populations at around a TFR of about 2.5 (2.62 for Mozambicans and 2.42 for South Africans in 2009).

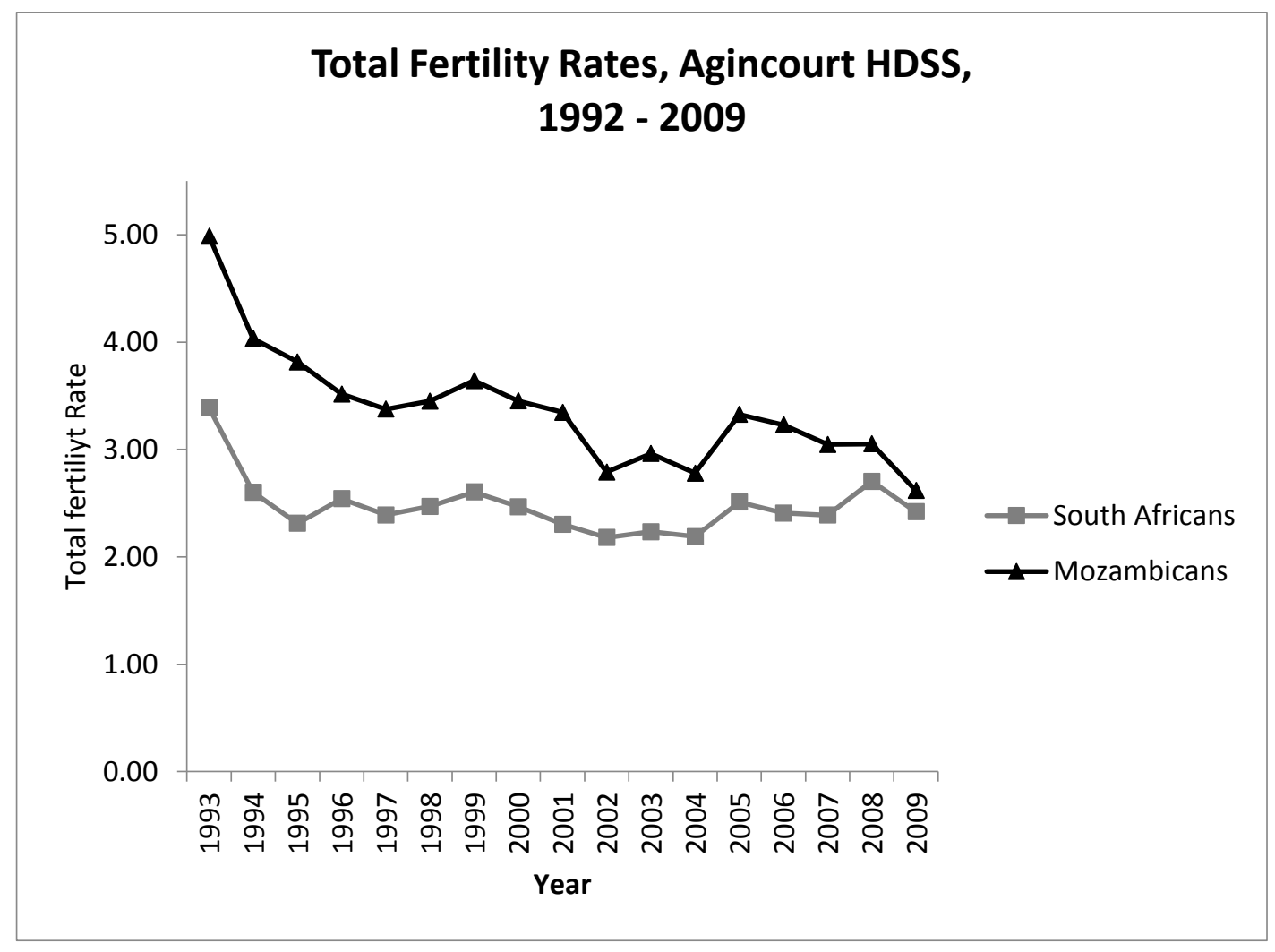

Figure 2: Trends in Total Fertility Rate in the Agincourt sub-district population by South African and Mozambican sub-population 


\section{Decomposition of fertility trends}

Table I shows that overall, fertility declined by about I.4 children per woman (last row of Column 2) between 1993 and 2009. A breakdown of total fertility rates over the period by observed peaks and troughs shows that fertility declined by about I.I children per woman between 1993 and 1995.

Thereafter, it rose slightly, by about 0.1 , between

1995 and 1999, resumed the declining trend between
1999 and 2002 where a reduction of about 0.5

children per woman was observed, and rose slightly again between 2002 and 2009. The observed slight increase from 1995 to 1999 and 2002 to 2009

suggest stall in fertility in these periods.

Table I: Decomposition of change in TFR at the Agincourt HDSS from I993 to 2009
Period
Total $\triangle T F R$
Change in TFR due to

\begin{tabular}{ccccccccc} 
& & \multicolumn{2}{c}{$\Delta$ TFRsa } & \multicolumn{2}{c}{$\Delta$ TFRmz } & \multicolumn{2}{c}{$\Delta$ Proportion (SA) } \\
\cline { 2 - 9 } & Actual & $\%$ & Actual & $\%$ & Actual & $\%$ & Actual & $\%$ \\
\hline 1 & 2 & 3 & 4 & 5 & 6 & 7 & 8 & 9 \\
\hline $1993-1995$ & -1.106 & 100 & -0.746 & 67.51 & -0.361 & 32.67 & 0.002 & -0.18 \\
\hline $1995-1999$ & 0.131 & 100 & 0.206 & 156.62 & -0.050 & -38.26 & -0.024 & -18.35 \\
\hline $1999-2002$ & -0.549 & 100 & -0.302 & 55.02 & -0.244 & 44.44 & -0.003 & 0.54 \\
\hline $2002-2009$ & 0.118 & 100 & 0.169 & 143.65 & -0.050 & -42.27 & -0.002 & -1.38 \\
\hline $1993-2009$ & -1.405 & 100 & -0.680 & 48.41 & -0.690 & 49.14 & -0.034 & 2.44 \\
\hline
\end{tabular}

$\%$

Percent

Total $\triangle T F R$

Total change in TFR

$\triangle$ TFRsa

Change in fertility of South African women

$\triangle T F R m z$

Change in fertility of Mozambican women

$\triangle$ Proportion (SA)

Change in proportion of South African women

Decomposition results in column 4 show that the fertility of resident South Africans increased in the two periods where stall was observed whereas the Mozambicans fertility declined in all cases (column 6). Further, the decomposition results show that the changes in fertility levels as a result of changes in proportion of South African women were negligible (column 8). Table I also shows that the fall in TFR between 1993 and 2009 was contributed to almost equally by the two population groups. The contribution from the South African population coming from the inter-period increase in fertility levels while the contribution of the Mozambicans seem to come from actual fall in fertility especially around the observed stall periods. In sum, these results link the observed stall in the two periods to the rise in the fertility level of resident South Africans. 
Vol. 28, No. I: Suppl on Population Issues in South Africa, May, 2014

\section{Changes in age pattern of fertility at stall periods}

Further analysis presented in Figures $3 a$ and $3 b$ show that the reversal in the downward trend of fertility among South African women between the stall periods are attributable to increase in the agespecific fertility rates (ASFR) of women aged 20-24 and 25-29. For the Mozambican women, the latter years' ASFRs were lower at all ages in the 19951999 period, but were slightly higher for age groups 25-29 and 30-34 years in the 2002-2009 period. This increase was however overshadowed by the decline in the other age groups, in particular, the 20-24 age group.

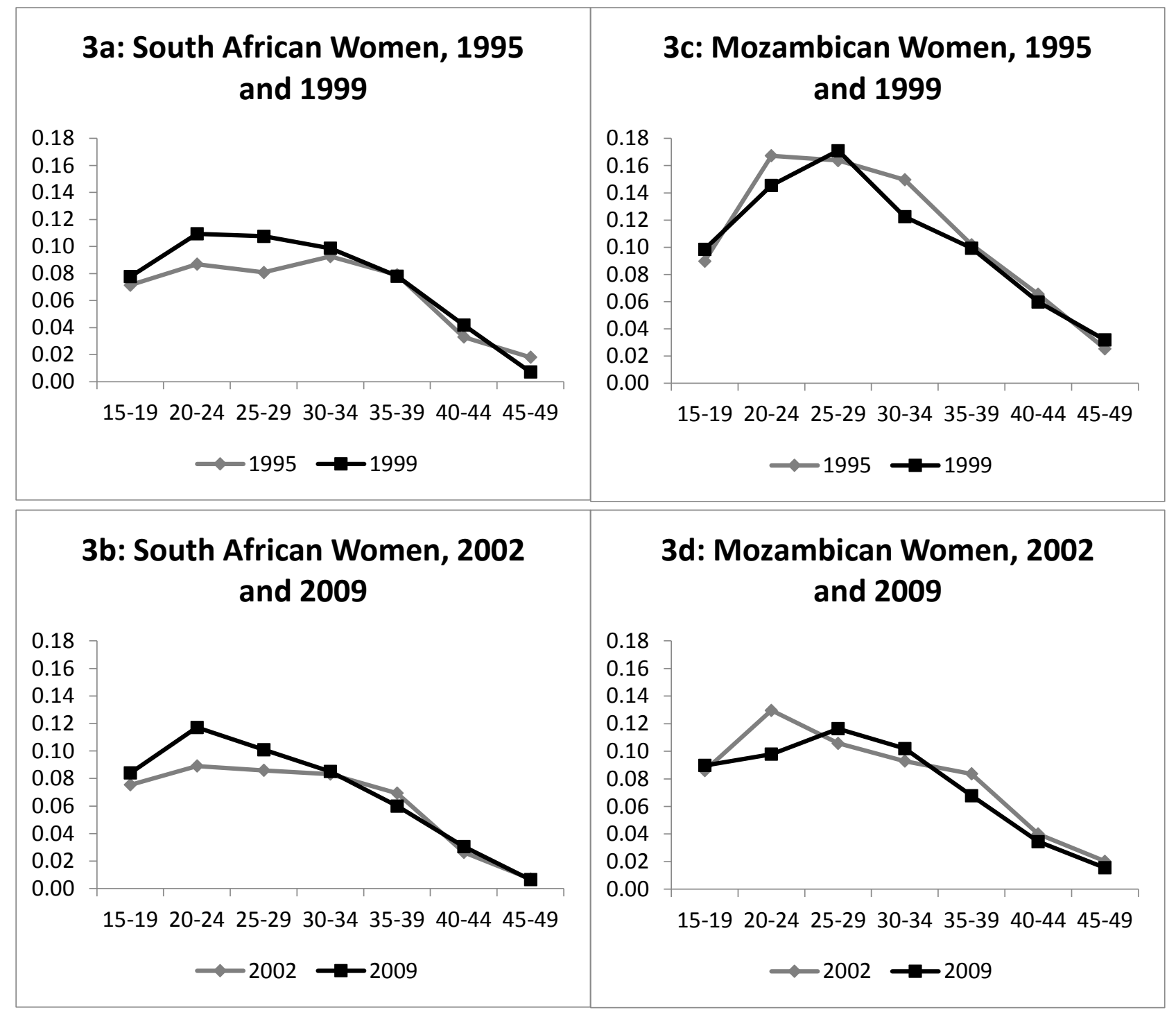

Figures 3: Age-specific fertility rates in the observed stall periods, 1995-1999 and 20022009 by Sub-Population

\section{Proportion of third births}

Williams et al. (2013) examined the timing of first and second births among former Mozambican refugees and South Africans in the Agincourt subdistrict. They found that between 1993 and 2009 former Mozambican refugees had adapted the childbearing patterns typical of South Africans - high percentages of first births to adolescents and then delayed second births. For first births from 19931995, approximately $70 \%$ of Mozambican's had a second birth within five years while approximately
$40 \%$ of South Africans had a second birth within 5 years. However, for first births occurring between 2003 and 2005, only about $40 \%$ of both former Mozambican refuges and South Africans had a second birth within five years. This finding partially explained how Mozambican women's fertility fell from 1993-2009. It does not, however, further our understanding of the overall stall in fertility decline or the observed increase in fertility among the South African population in the area. 
Due to the fact that fertility level has stalled at around 2.5 children per woman, we examined the proportion of women having a third birth in the two populations over time. Figure 4 shows that the proportion of women having a third birth has been increasing for South African women and decreasing for Mozambican women since around 2000.

\section{Contribution of the two population groups to 3rd birth at AHDSS}

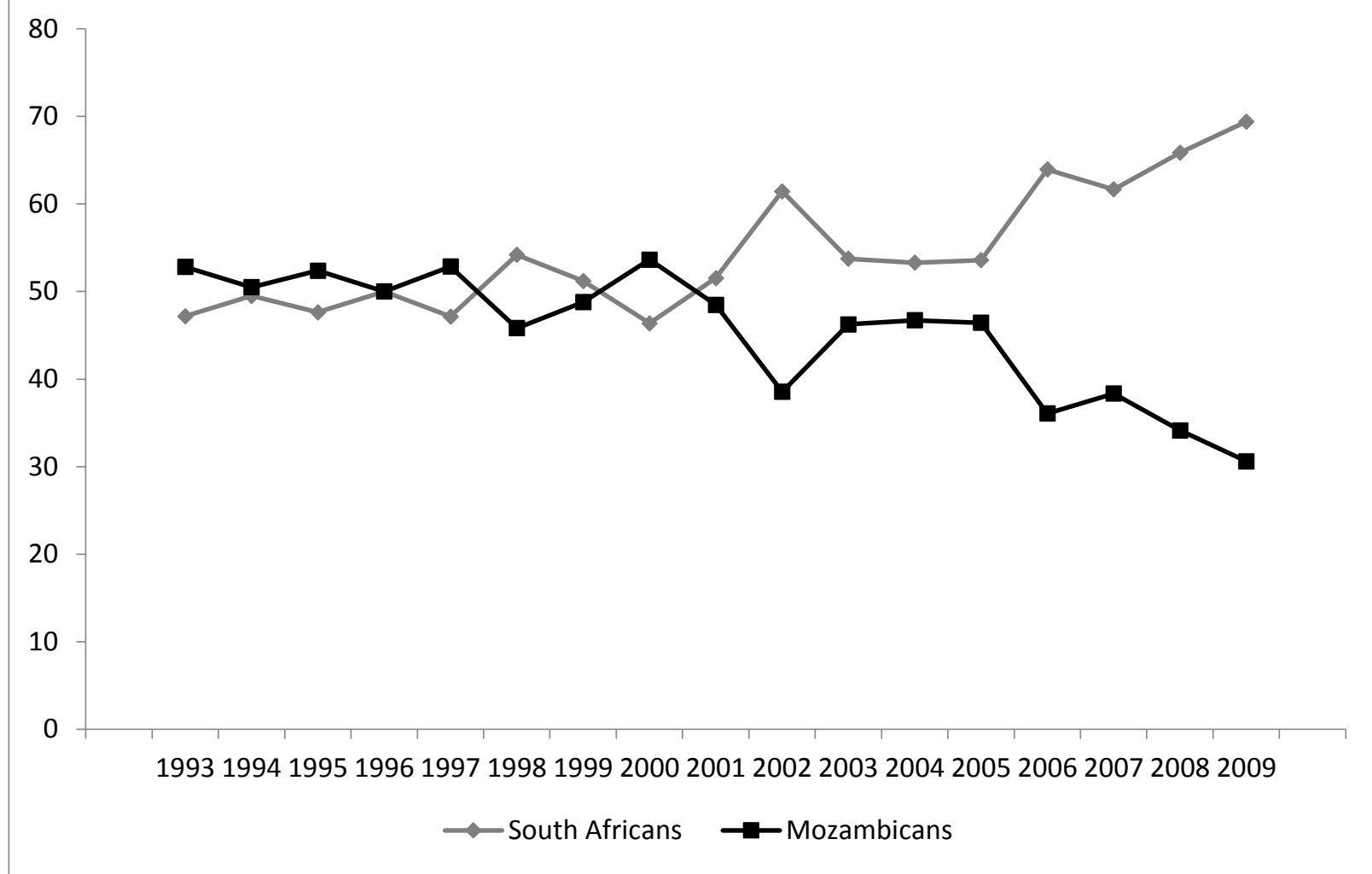

Figure 4: Proportion of Women Having a third Birth by Sub-population

\section{Discussion and conclusion}

The study examined the role of the fertility of former refugees of Mozambican origin in fertility decline and stall in northeast rural South Africa from 1993-2009. Fertility declined from around 4 children per woman in 1993 to about 2.5 in 2000 and has been relatively stable at the latter level for the last decade. Two periods of moderate stalls in fertility decline were observed, 1995-1999 and 2002-2009.

Contrary to expectation, the decomposition procedure carried out showed that increases in the fertility of South African women were responsible for the stalls in the fertility decline of the two periods. The age pattern of fertility over the stall periods also indicated increase in fertility level of South African women aged 20-29 years. The observed increase in the proportion of South African women residing at the site having a third birth since around year 2000 further corroborate the increase in fertility of South African women shown by the decomposition procedure and the age pattern of fertility analysis.

This study shows that the self-settled Mozambican refugees, resident at the Agincourt HDSS did not contribute to the reversal in the fertility decline of the area that hosts them. This suggests that, the influx of people displaced by war does not necessarily lead to (real or perceived) negative effect on the fertility levels and trend of the host community. Although the causes of the stall was not the objective of this paper, the factors that account for the reversal in the fertility trend of the South African women warrants more attention. For instance, the impact of HIV/AIDS and the rollout of treatment on fertility, including on any potential differential impact of HIV/AIDS and treatment on 
South African and Mozambican populations in the Agincourt sub-district is unclear.

Further, given the high levels of temporary labour migration in the area and that adult women are increasingly part of this stream, the potential impact of labour migration on fertility trend in the area needs to be comprehensively explored.

\section{Notes}

This is defined operationally as a failure of the national total fertility rate (TFR) to decline between two most consecutive estimates after an established trend of decline in fertility (Bongaarts, 2006; Shapiro \& Gebreselassie, 2008; Garenne, 2008).

${ }^{2}$ People have more children than wanted with the hope that even if some die, some will be left while for child replacement, another child is born when one dies.

\section{Acknowledgement}

We thank Christie Sennott and John B. Casterline for comments on earlier drafts. Versions of the study were presented at the 20II INDEPTH Scientific Conference, Maputo, and at the 2012 Population Association of America Meeting, San Francisco. The AHDSS has been funded by the Wellcome Trust, UK (grants 058893/Z/99/A; 069683/Z/02/Z; 085477/Z/08/Z), with support from the William and Flora Hewlett Foundation, National Institute on Aging (NIA) of the NIH, and the Andrew W. Mellon Foundation, USA. Fogarty International, the School of Public Health and Faculty of Health Sciences, University of the Witwatersrand, and the Medical Research Council, South Africa, have provided valuable support.

\section{References}

Bastick, M., Grimm, K. \& Kunz, R. 2007. Sexual violence in armed conflict: global overview and implications for the security sector. Geneva: Geneva Centre for the Democratic Control of Armed Forces.

http://www.essex.ac.uk/armedcon/story id/sexualvi olence conflict full\%5BI\%5D.pdf

Bloom, D. E. 20II. 7 Billion and Counting. Science, 333 (6042. p. 562-569.

Bongaarts, J. 2002. The end of the fertility transition in the developing world. Population and Development Review. 28. P. 419-443.

Bongaarts, J. 2006. The causes of stalling fertility transitions. Studies in Family Planning. 37. P. I-I6.

Bongaarts, J. 2008. Fertility transitions in developing countries: progress or stagnation? Studies in Family Planning. 39. P. 105-II0.
Bratti, M. 2003. Labour Force Participation and Marital Fertility of Italian Women: The Role of Education. Journal of Population Economics. 16(3). p. 525-554.

Caldwell, J. C. \& Caldwell, P. 2002. The Fertility Transition in Sub-Saharan Africa. www.hsrcpress.ac.za

Camlin, C., Garenne, M. \& Moultrie, T. 2004. Fertility trends and patterns in a rural area of South Africa in the context of HIV/AIDS. African Journal of Reproductive Health. 8(2). P.38-54.

Collinson, M. A. 2009. Striving against adversity: The dynamics of migration, health and poverty in rural South Africa. PhD Dissertation. Department of Public Health and Clinical Medicine, Umeå University, Sweden.

http://su.diva-

portal.org/smash/get/diva2:212616/FULLTEXTOI

Collinson, M. A. 20I0. Striving against adversity: The dynamics of migration, health and poverty in rural South Africa. Global Health Action. 3. doi 10.3402/gha.v3i0.5080.

Ezeh, A., Mberu, B. \& Emina, J. 2009. Stall in fertility decline in Eastern African countries: regional analysis of patterns, determinants and implications. Philosophical Transactions of the Royal Society B (Biological Sciences). 364. p. 29913007.

Garenne, M., Tollman, S., Collinson, M. \& Kahn, K. 2007 Fertility trends and net reproduction in Agincourt, rural South Africa, 1992-2004. Scandinavian Journal of Public Health. 35. p. 68-76.

Garenne, M., Tollman, S. \& Kahn, K. 2000. Marital and premarital fertility in a rural area of South Africa: A challenge to existing population policy. Studies in Family Planning. 31. p. 47-54.

Garenne, M. 2008. Situations of fertility stall in subSaharan Africa. African Population Studies. 23(2). p. $173-188$.

Gendell, M. 1989. Stalls in the Fertility Decline in Costa Rica and South Korea. International Family Planning Perspectives. I5(I). p. I5-2I.

Gomez-Olive, F. X., Angotti, N., Houle, B., Klipstein-Grobusch, K., Kabudula, C., Menken, J., Williams, J., Tollman, S. \& Clark, S. J. 2013. Prevalence of HIV among those 15 and older in rural South Africa. AIDS Care: Psychological and Socio-medical Aspects of AIDS/HIV. p. I-7. http://dx.doi.org/I0.1080/09540 I21.2012.7507| $\underline{0}$ 
Gustafsson, S. \& Worku, S. 2007. Teenage Motherhood and long-run outcomes in South Africa. Tinbergen Institute Discussion Paper. TI 2007-024/3.

http://www.tinbergen.nl/discussionpapers/07024.pdf Human Security Brief. 2006. Overview. Human Security Centre. The University of British Colombia, Canada. p. 2.

http://www.hsrgroup.org/docs/Publications/HSB200 6/2006HumanSecurityBrief-FullText.pdf

Kahn, K., Collinson, M. A., Gomez-Olive, F. X.,' Mokoena, O., Twine, R., Mee, P., Afolabi, S. A., Clark, B. D., Kabudula, C. W., Khosa, A., Khoza, S., Shabangu, M. G., Silaule, B., Tibane, J. B., Wagner, R. G., Garenne, M. L., Clark, S. J. \& Tollman, S. M.. 2012. "Profile: Agincourt Health and Socio-demographic Surveillance System." International Journal of Epidemiology 4I. p. 988I00I.

Kahn, K., Tollman, S. M., Collinson, M. A., Clark, S. J., Twine, R., Clark, Benjamin D., Shabangu, M., Gómez-Olivé, F. X., Mokoena, O. and Garenne, M. L. 2007. Research into health, population and social transitions in rural South Africa: Data and methods of the Agincourt Health and Demographic Surveillance System. Scandinavian Journal of Public Health, 35(3). p. 8- 20

Kaufman, C. E., de Wet, T. \& Stadler, J. 200I. Adolescent and Parenthood in South Africa. Studies in Family Planning. 32(2). p. 147-160.

Lindstrom, D. P. \& Woubalem, Z. 2003. The demographic components of fertility decline in Addis Ababa, Ethiopia: a decomposition analysis. GENUS, LIX (No. 3-4), I47-I58.

Moultrie, T. A. \& Timæus, I. M. 2002. Trends in South African fertility between 1970 and 1998: An analysis of the 1996 Census and the 1998 Demographic and Health Survey. Cape Town: Medical Research Council. <http://www.mrc.ac.za/bod/trends.pdf.>

Moultrie, T. A., Hosegood, V., McGrath, N., Hill, C., Herbst, K., \& Newell, M. 2008. Refining the Criteria for Stalled Fertility Declines: An Application to Rural KwaZulu-Natal, South Africa, 1990-2005. Studies in family planning. 39(I). p. 39-48.

O'Hare, B. \& Southall, D. 2007. First do no harm: the impact of recent armed conflict on maternal and child health in sub-Saharan Africa. Journal of the Royal Society of Medicine. 100. p. 564-570.
Palamuleni, M., Kalule-Sabiti, I. \& Makiwane, M. 2007. Fertility and childbearing in South Africa. In Amoateng, A.Y. \& Heaton, T.B. (eds). Families and households in post-apartheid South Africa: socio-demographic perspectives. Cape Town: HSRC Press.

Retherford, R. D. \& Ogawa, N. 1978. Decomposition of the change in the total fertility rate in the Republic of Korea, 1966-1970. Social Biology, 25(2). p. II5-I 27.

Schindler, K. \& Brück, T. 20II. The effects of conflict on fertility in Rwanda, Discussion Paper, German Institute for Economic Research, No. II 43.

http://www.econstor.eu/bitstream//0419/57256/ I/68937433X.pdf

Schoumaker, B. 2008. Stalls in fertility transitions in sub-Saharan Africa: real or spurious? IUSSP seminar on human fertility in Africa. Trends in the last decade and prospects for change, 16-18 September 2008, Cape Coast, Ghana.

www.uclouvain.be/cps/ucl/doc/demo/.../DT SPED 30 corrige.pdf

Shapiro, D. \& Tambashe, B. O. 2002. Fertility Transition in Urban and Rural Sub-Saharan Africa: Primary Evidence of a Three-Stage Process. Journal of African Policy Issues, 8(2-3). p. I03-I 27.

Shapiro, D. \& Gebreselassie, T. 2008. Fertility transition in sub-Saharan Africa: falling and stalling. African Population Studies. 23. p. 3-23.

Sibanda, A. \& Zuberi, T. 1999. Contemporary Fertility Levels and Trends in South Africa: Evidence from Reconstructed Census Birth Histories. ACAP Working Paper No 8. The African Census Analysis. Pennsylvania: University of Pennsylvania.

Statistics South Africa. 20II. Mid-year Population Estimates.

http://www.statssa.gov.za/keyindicators/keyindicator s.asp

Swartz, L. 2002. Fertility transition in South Africa and its implications on the four major population groups. UN Population Bulletin; 48-49 (Special Issue on Completing the Fertility Transition). p. 487-500.

Udjo, E. 2003. A re-examination of levels and differential fertility in SA from recent evidence. Journal of Biosocial Science. 35(I). p. 4I3-43I. 
United Nations High Commissioner for Refugees. 2012. Global trends 201I: a year in crises. http://www.unhcr.org/statistics.

Verwimp, P. \& Van Bavel, J. 2005. Child survival and fertility of refugees in Rwanda. European Journal of population. 2I. p. 7I-290.

Westoff, C. F. \& Cross, A. R. 2006. The stall in the fertility transition in Kenya, DHS Analytic Studies, Number 9, Calverton, NY: ORC Macro.

Williams, J., Ibisomi, L., Sartorius, B., Kahn, K., Collinson, M., Tollman, S. \& Garenne, M. 2013. Convergence in fertility of South Africans and Mozambicans in rural South Africa, 1993-2003. Global Health Action (Suppl I), 6: 19236. p. 20-26.

\section{http://dx.doi.org/10.3402/gha.v6i0.19236}

\section{Authors contribution:}

LI conceptualized the paper, analysed the data, drafted the manuscript and coordinated submission and response to reviewers; JW contributed to the data analysis and writing of the manuscript, response to reviewers and proof reading the manuscript; MAC contributed to the data analysis and writing of the paper; ST provided scientific leadership, introduced and led the health and sociodemographic surveillance system.

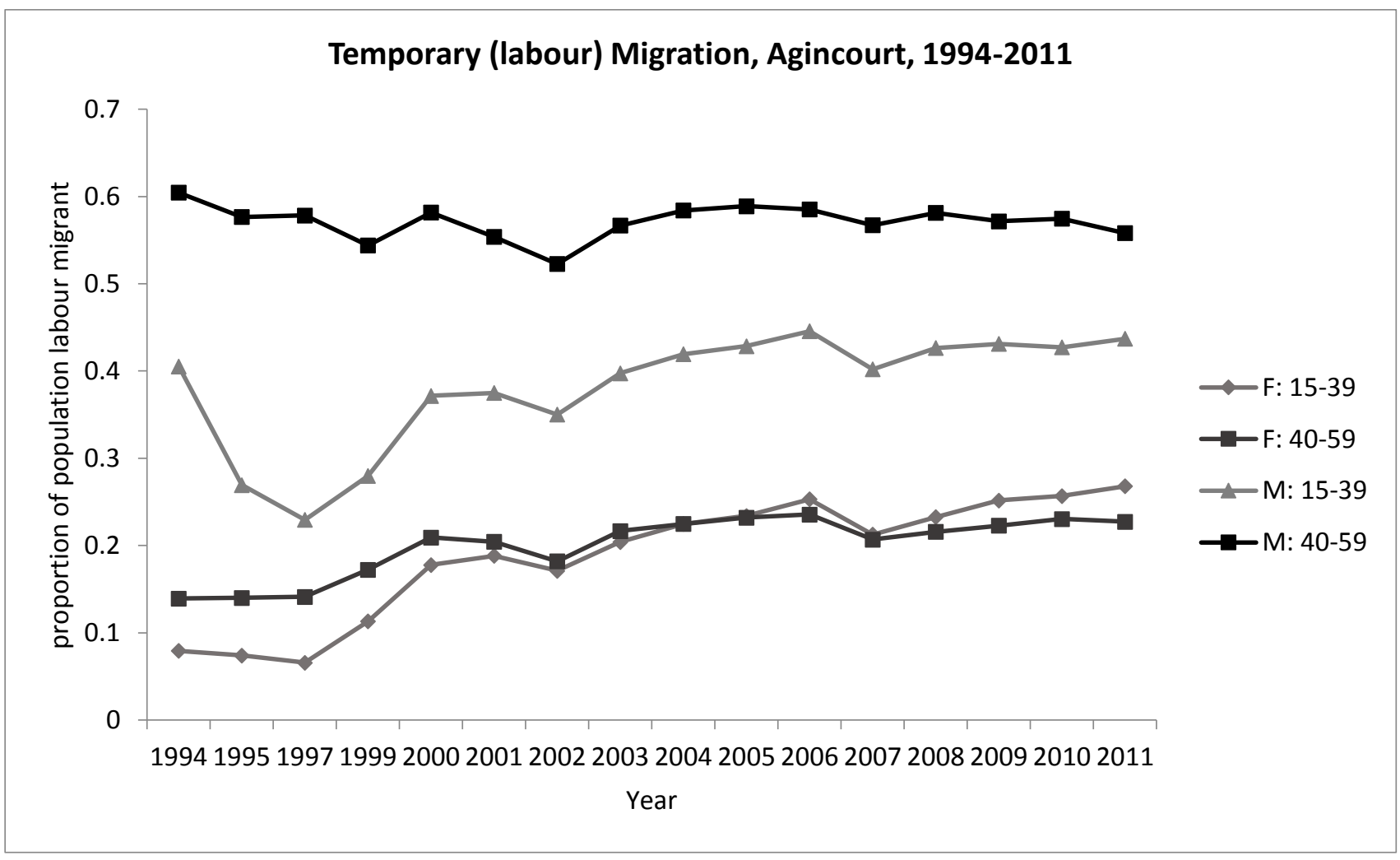

Appendix: Trends in temporary (labour) migration from the Agincourt sub-district, by sex and broad age categories 